\title{
Possibilities of using carbon dioxide as fillers for heat pipe to obtain low- potential geothermal energy
}

\author{
M. Kasanický ${ }^{1, a}$, S. Gavlas ${ }^{1}$, M Vantúch $^{1}$ and M. Malcho ${ }^{1}$ \\ ${ }^{1}$ University of Žilina, Faculty of Mechanical Engineering, Department of Power Engineering, Univerzitna 1, \\ 01026 Žilina, Slovakia
}

\begin{abstract}
The use of low-potential heat is now possible especially in systems using heat pumps. There is a presumption that the trend will continue. Therefore, there is a need to find ways to be systems with a heat pump efficiencies. The usage of heat pipes seems to be an appropriate alternative to the established technology of obtaining heat through in-debt probes. This article describes a series of experiments on simulator for obtaining low-potential geothermal energy, in order to find the optimal amount of carbon dioxide per meter length of the heat pipe. For orientation and understanding of the conclusions of the experiment, the article has also a detailed description of the device which simulates the transport of heat through geothermal heat pipes.
\end{abstract}

\section{Heat the tube in use in geothermal field}

Heat pipe is a device for intensive heat flux transfer while maintaining a small temperature difference. In principle, the heat transport is ensured by means of evaporation and condensation of the working substance.

Main areas of standard gravitational heat pipe are shown in figure 1 Heat pipe in a longitudinal direction consists of evaporator, condensator and the adiabatic area. Adiabatic region is a dividing element between the evaporator and condenser regions.

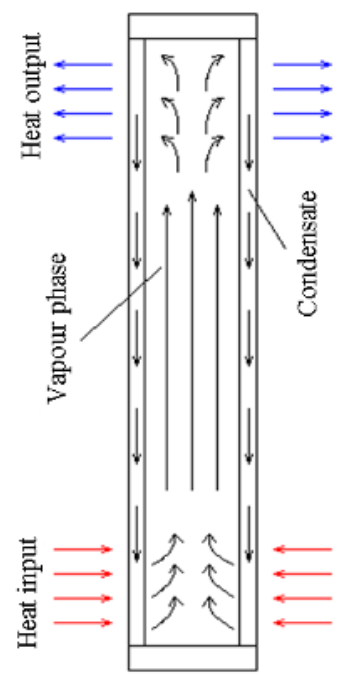

Fig. 1. Schematic of heat pipe.
In the evaporating part of the working fluid in liquid form is heated, and consequently begins to evaporate. Vapor of the working fluid passes through the adiabatic region to the condenser, where it releases its heat. This cooled material returns in the form of condensate to the evaporator (by gravity in gravity tubes, or by capillary depression in capillary tubes), which again passes into the steam phase and the circuit is closed.

Performance of the heat pipe is at first determined by temperature gradient between the evaporator and condenser, it also affects the value the heat of evaporation of working fluid, but also the walls of the tube material.

These facts make the heat pipe suitable means for obtaining geothermal heat as an alternative to in-depth probes, which are used mostly as working medium solution of ethylene glycol in water.

Heat recovery by heat pipes has over standard way of raising geothermal heat advantage, it does not need to use the mechanical work of circulation pump to transporting working medium trough the geothermal probe, as transport of the work medium is as due to the correct function of the heat pipe - thus working fluid evaporation.

\subsection{Filling of the heat pipe}

The basic criterion for choosing the appropriate charges for the heat pipe in geothermal field is the temperature of evaporation. This temperature must be to the extent that it has the ability to vaporize the working fluid at low temperatures. Therefore substances under normal conditions $\left(0{ }^{\circ} \mathrm{C}, 101.325 \mathrm{kPa}\right)$ in liquid form do not

\footnotetext{
${ }^{a}$ martin.kasanicky@fstroj.uniza.sk
} 
come as consideration a heat pipe filling into. In fact, the temperature of borehole is between -10 to $10\left({ }^{\circ} \mathrm{C}\right)$. Because of this, the materials suitable for filling the heat pipe will be substances, which is having a melting point lower than this range (with respect to higher pressure, which tube is).

\section{Carbon dioxide as a heat pipe filling}

Carbon dioxide is atmospheric trace gas (atmospheric content $0.0314 \%$ by volume) composed of two oxygen atoms and one carbon atom. It is colorless, flammable, reactive and less heavy than air. Carbon dioxide produced as a product of normal biological processes, such as respiration and fermentation and as a product of burning carbon compounds in the air. Basic physical properties of carbon dioxide are in table 1.

Table 1. Physical properties of carbon dioxide.

\begin{tabular}{|l|l|}
\hline Chemical formula & $\mathrm{CO}_{2}$ \\
\hline Molecular weight & $44,01 \mathrm{~g} . \mathrm{mol}^{-1}$ \\
\hline Melting point (at a pressure of $0.5 \mathrm{MPa})$ & $-56.6^{\circ} \mathrm{C}$ \\
\hline $\begin{array}{l}\text { Boiling point (at a pressure of } 101.235 \\
\mathrm{kPa})\end{array}$ & $-78.5^{\circ} \mathrm{C}$ \\
\hline The critical temperature & $31.01^{\circ} \mathrm{C}$ \\
\hline The critical pressure & $7.386 \mathrm{MPa}$ \\
\hline Gas density $\left(0^{\circ} \mathrm{C}, 101.325 \mathrm{kPa}\right)$ & $1.965 \mathrm{~kg} / \mathrm{m}^{3}$ \\
\hline Liquid density $\left(-56.6^{\circ} \mathrm{C}, 0.52 \mathrm{MPa}\right)$ & $1.178 \mathrm{~kg} / \mathrm{dm}^{3}$ \\
\hline Heat of vaporization & $571.08 \mathrm{~kJ} / \mathrm{kg}$ \\
\hline
\end{tabular}

An important feature of carbon dioxide is, that under normal (atmospheric) pressure sublimates. Therefore, it is necessary to operate them at higher pressures, namely it is the lowest pressure 51.85 bar, which corresponds to the triple point pressure.

\section{Model of the borehole}

The measurement was to compare the behavior of the temperature and pressure depending on the amount of carbon dioxide in the working simulator for obtaining low-potential geothermal heat. Experiments can be considered successful, when the state of working fluid is in the saturation curve.

The whole apparatus to simulate the transport of low-potential geothermal energy consists of three areas.

The first circuit is a single simulator shown in figure 2 . The device consists of a corrugated pipe $\varnothing 500$ $\mathrm{mm}$ and length of $6220 \mathrm{~mm}$, about of which is $600 \mathrm{~m}$ of glowing Devi cables muffled. These cables are divided into three independently controllable sections and used to simulate the action of the earth's heat. Inside the corrugated tube is smooth PVC sewer pipe diameter of $\varnothing 200 \mathrm{~mm}$ and $5000 \mathrm{~mm}$ length. The space between the two tubes is filled with sand. In inner tube is placed 4 plastic tubes $\varnothing 42 \times 3.5 \mathrm{~mm}$ length of $6 \mathrm{~m}$, which act as heat pipes in the simulator.

The measuring of temperatures in this part of the device is performed by using 24 thermocouples $\mathrm{Ni}, \mathrm{Cr}$ $\mathrm{Ni}$, which are located in six locations in the vertical direction and at four locations in the radial direction, which are distributed regularly between internal and external sewer pipe.
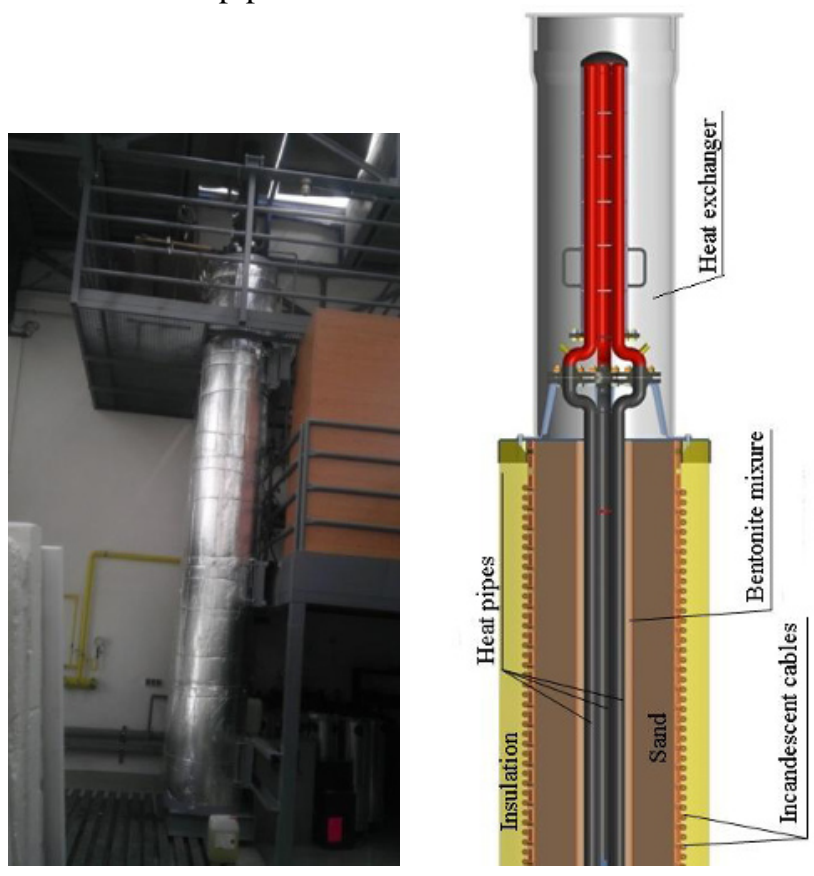

Fig. 2. Geothermal heat transport simulator

(to the left the overall simulator view, schematic section through on the right)

The second loop is a cooling circuit that is used for removing heat from the simulator, is represented by a Julabo F2503 cooler, heat exchanger for heat transfer to the cooling system (which is placed on top of the simulator) and piping system between the refrigeration unit and heat exchanger. The third circle represents the refill and wastegate need to change the amount of working fluid (and the pressure) within a heat pipe. The circuit is also equipped with safety fittings against exceeding the allowable pressure in the device.

\section{Analysis of measurement results}

Measurement consisting of four experiments, and each experiment was used with different amounts of carbon dioxide. Measurements were conducted at the same initial conditions, the simulation of the geothermal heat made by glowing cables has been turned off.

Table 2. The initial conditions for measurements 1 through 4 .

\begin{tabular}{|c|c|}
\hline $\begin{array}{c}\text { The temperature in the } \\
\text { laboratory }\end{array}$ & $20^{\circ} \mathrm{C}$ \\
\hline $\begin{array}{c}\text { The average temperature } \\
\text { of all the thermocouples }\end{array}$ & $18.829^{\circ} \mathrm{C}$ \\
\hline $\begin{array}{c}\text { Coolant temperature at } \\
\text { cooler }\end{array}$ & $-5^{\circ} \mathrm{C}$ \\
\hline Duration of measurement & $48 \mathrm{~h}$ \\
\hline
\end{tabular}

After filling simulator with certain amount of experimental working fluid has been possible to register 
pressure changes in the simulator, the initial pressure in the simulator was equal barometric pressure. The quantity of carbon dioxide and the pressure all 4 experiments are shown in table 3 .

Table 3. Quantities of carbon dioxide and pressure measurements pressure

\begin{tabular}{|c|c|c|c|}
\hline & $\begin{array}{c}\text { The } \\
\text { amoun } \\
\text { t of } \\
\mathrm{CO}_{2} \\
(\mathrm{~kg})\end{array}$ & $\begin{array}{l}\text { The pressure } \\
\text { at the } \\
\text { beginning of } \\
\text { the } \\
\text { measurement } \\
\text { (bar) }\end{array}$ & $\begin{array}{l}\text { The pressure } \\
\text { at the end of } \\
\text { the } \\
\text { measurement } \\
\text { (bar) }\end{array}$ \\
\hline $\begin{array}{l}\text { Measuremen } \\
\text { t No. } 1\end{array}$ & 1.5 & 24.1 & 23.94 \\
\hline $\begin{array}{l}\text { Measuremen } \\
\text { t No. } 2\end{array}$ & 2.5 & 27.82 & 27.77 \\
\hline $\begin{array}{l}\text { Measuremen } \\
\text { t No.3 }\end{array}$ & 4.0 & 33.79 & 32.24 \\
\hline $\begin{array}{l}\text { Measuremen } \\
\text { t No. } 4\end{array}$ & 4.5 & 35.79 & 32.42 \\
\hline
\end{tabular}

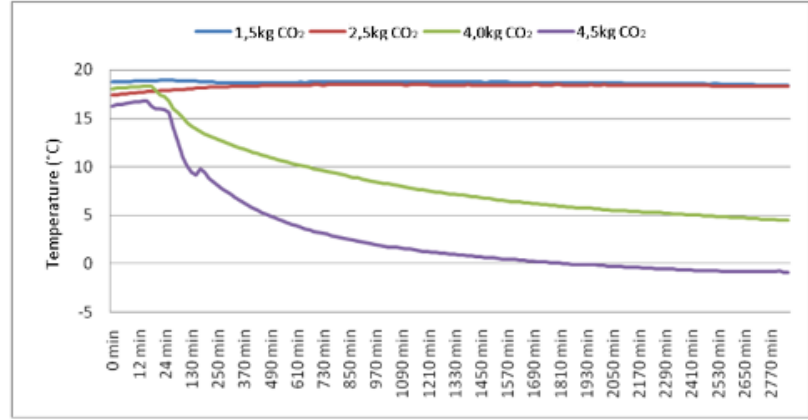

Fig. 3. Graphical dependence of the average temperature of the heat pipe in 48 hours

Proper function of the heat pipe would indicate a drop in temperature during the measurement. For the first and second measurements the temperatur did not fall in in the tube, or just fell on top of the simulator, which was caused by the cooling circuit activity. This means that the heat pipe not work properly because all working fluid in the tube was in the gas phase (or vapor phase) and it is capable of transporting heat with conduction and convection, not by means of phase transformations. Phase diagrams for the first and second measurements are shown in figure 4 th and 5 th.

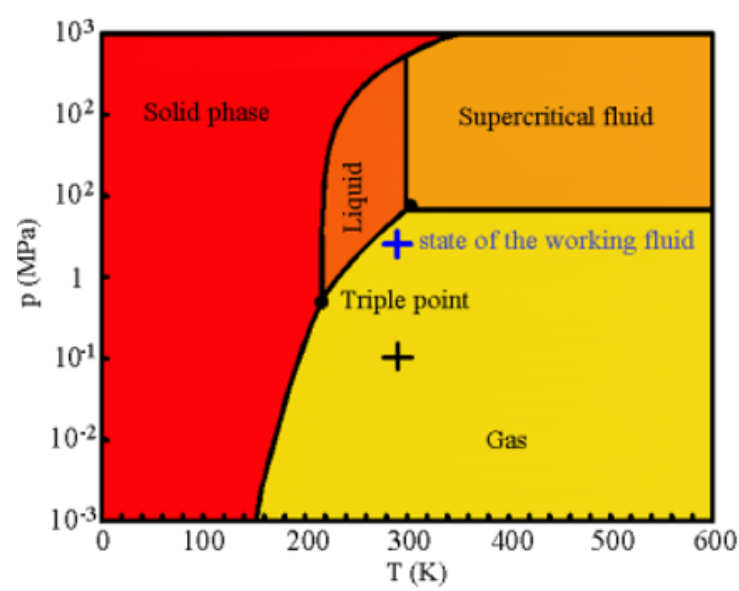

Fig. 4. State diagram for carbon dioxide of $1.5 \mathrm{~kg}$ and $2.5 \mathrm{~kg}$

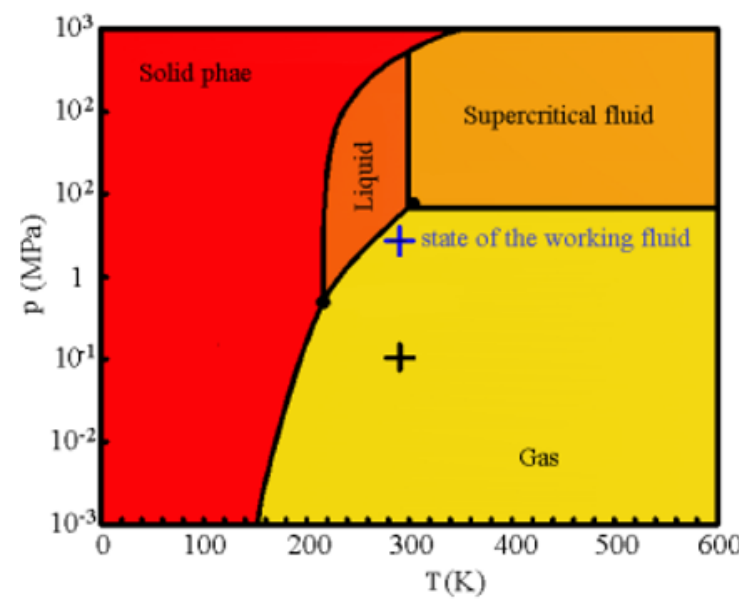

Fig. 5. State diagram for carbon dioxide of $2.5 \mathrm{~kg}$

For measurements no. 3 and 4 (figure 6, 7) is already evident temperatures drop what says about the correct functioning of the heat pipe, so the cycle of evaporation and condensation of the working substance.

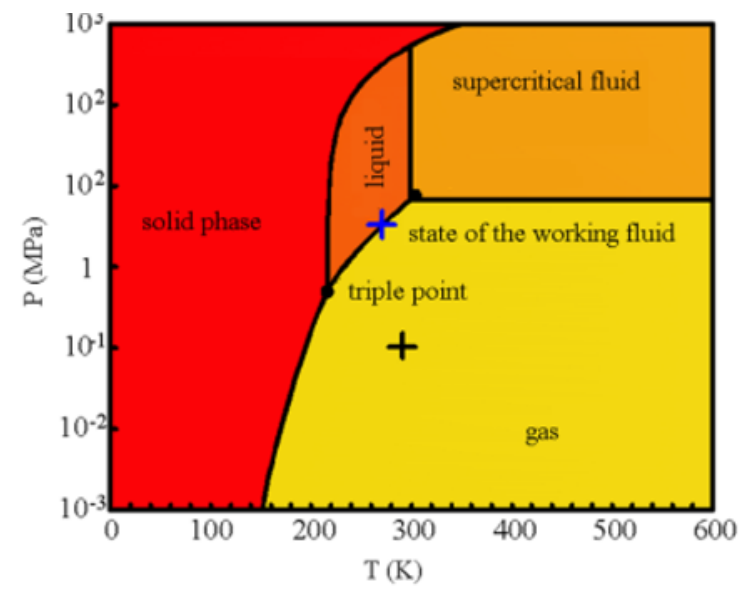

Fig. 6. State diagram for the amount of carbon dioxide $4.0 \mathrm{~kg}$ 


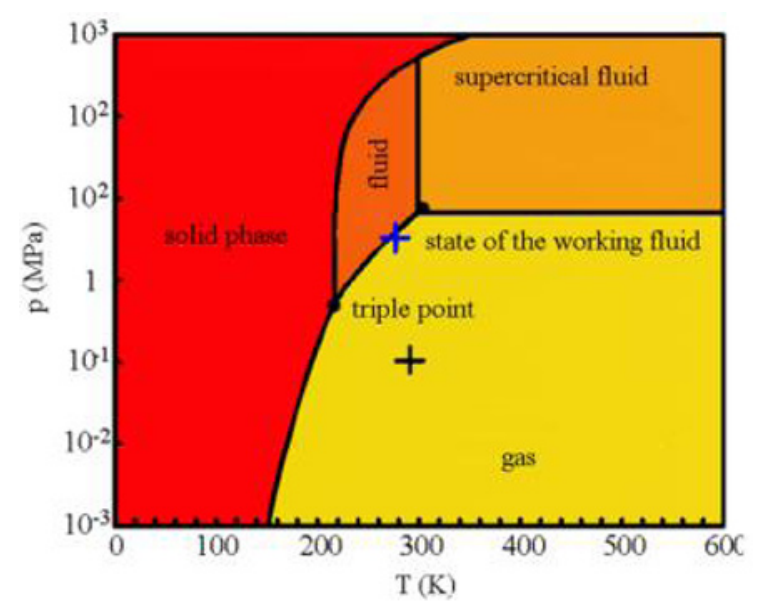

Fig. 7. State diagram for the amount of carbon dioxide $4.5 \mathrm{~kg}$

For a more detailed study of temperatures in the heat pipe in the vertical direction figure 8 shows the measurement record with $4.5 \mathrm{~kg}$ of carbon dioxide

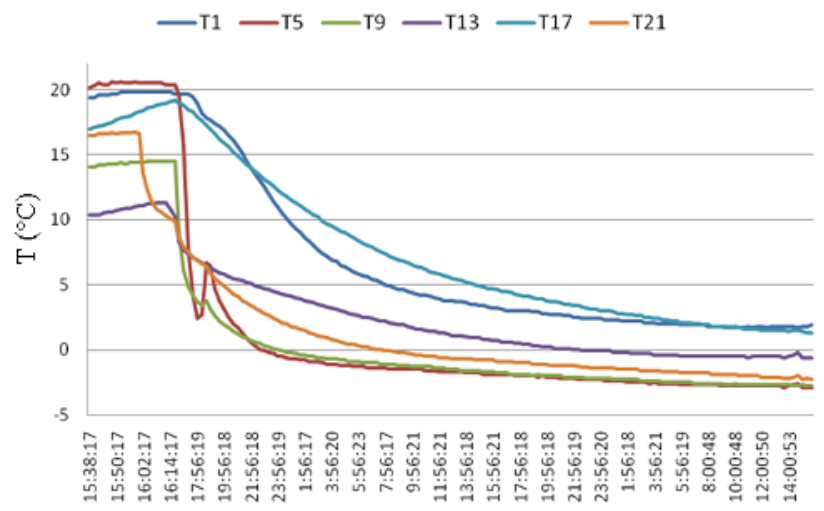

Obr. 8. Graphical dependence of the temperature in experiment with $4.5 \mathrm{~kg}$ of carbon dioxide

$\mathrm{T} 1$ is the lowest measured temperature of the heat pipe, T24 at the highest temperature and the other temperatures is located between them. Temperature at the beginning of measurement have not been stabilized and ranged between about 10 to $20^{\circ} \mathrm{C}$. This is due to insufficient clearance for the previous temperature measurements.

Table 4 is showing average thermal power determined by the quantities of heat method according to the equation 1:

$$
Q=\dot{m} \cdot c \cdot \Delta t(\mathrm{~W})
$$

The value of specific heat capacity has been set by manufacturer of heat transfer antifreeze Thermal $\mathrm{H}$ (which circulates in the cooling system) as $\mathrm{c}=3328$ $\left(\mathrm{J} / \mathrm{kg}^{1} . \mathrm{K}^{1}\right)$.
Table 4. The average value of the mass flow rate, temperature at the inlet and outlet of the heat exchanger and cooling system power transmitted

\begin{tabular}{|l|l|l|l|l|}
\cline { 2 - 5 } \multicolumn{1}{c|}{} & $\mathrm{m}(\mathrm{kg} / \mathrm{s})$ & $\mathrm{t} 1\left({ }^{\circ} \mathrm{C}\right)$ & $\mathrm{t} 2\left({ }^{\circ} \mathrm{C}\right)$ & $\mathrm{P}(\mathrm{W})$ \\
\hline $\begin{array}{l}\text { Measureme } \\
\text { nt No.1 }\end{array}$ & 0.194 & -4.208 & -4.245 & -23.5 \\
\hline $\begin{array}{l}\text { Measureme } \\
\text { nt No.2 }\end{array}$ & 0.194 & -4.205 & -4.247 & -24.0 \\
\hline $\begin{array}{l}\text { Measureme } \\
\text { nt No.3 }\end{array}$ & 0.190 & -4.059 & -3.876 & 115.8 \\
\hline $\begin{array}{l}\text { Measureme } \\
\text { nt No.4 }\end{array}$ & 0.195 & -4.172 & -3.832 & 220.1 \\
\hline
\end{tabular}

The first two heat performances are in negative territory, which means that instead of heat from the cooling system simulator offtake, basically as if it was delivered. But this is not possible because of temperature of refrigerant. This is due to the fact that the calculated performances have not included the heat gains to the external environment, on top of the simulator.

The third and fourth measure, unlike the first two already showing positive heat output and it is seen that the difference between the third and fourth measurement was $104.3 \mathrm{~W}$ and the increase in the amount of $0.5 \mathrm{~kg}$ of $\mathrm{CO} 2$ is almost doubling.

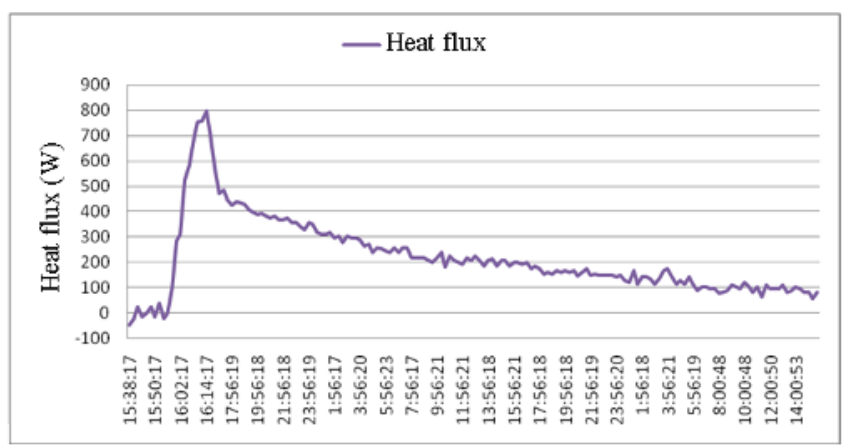

Fig. 10. Graphical dependency of the transmitted cooling circuit when measured with $4.5 \mathrm{~kg}$ of carbon dioxide

Length of the heat pipe is $6 \mathrm{~m}$. Performance is reduced by the amount of working fluid in length are found in Table 5. There are only the successful experiments.

Table 5. Evaluation of the measurement of the quantity of working fluid

\begin{tabular}{|l|l|l|l|l|}
\hline $\begin{array}{l}\text { Measurement } \\
\text { no. }\end{array}$ & $\begin{array}{l}\text { Weight } \\
\text { of the of } \\
\text { working } \\
\text { substance } \\
(\mathrm{kg})\end{array}$ & $\begin{array}{l}\text { Weight } \\
\text { of the } \\
\text { Working } \\
\text { fluid per } \\
\text { unit } \\
\text { length } \\
\text { of a } \\
\text { single } \\
\text { tube } \\
\text { (kg/m) }\end{array}$ & $\begin{array}{l}\text { Heat } \\
\text { output } \\
(\mathrm{W})\end{array}$ & $\begin{array}{l}\text { Heat } \\
\text { output } \\
\text { reduced } \\
\text { the } \\
\text { length } \\
\text { of the } \\
\text { heat } \\
\text { pipes } \\
(\mathrm{W} / \mathrm{m})\end{array}$ \\
\hline 3 & 0.1675 & 115.8 & 19.3 \\
\hline 4 & 4.0 & 0.1875 & 220.1 & 36.7 \\
\hline
\end{tabular}


From the table it can be concluded that at the fourth measurement with a working fluid $4.5 \mathrm{~kg}$ of carbon dioxide simulator is able to obtain $36.7 \mathrm{~W} / \mathrm{m}$ without providing heat from the four tubes. This performance would obviously with increasing duration of the experiment declined. The optimal amount of $\mathrm{CO}_{2}$ per meter of depth seems to $0.1875 \mathrm{~kg} / \mathrm{m}$.

\section{Conclusion}

Compared to conventional method of obtaining lowpotential heat with the in-depth probes as the primary energy source for the heat pump, the use of heat pipes haves advantage of the absence of pumping work, which is continuous with a reduction in the cost of heat. The results of measurements with carbon dioxide says that the working fluid of heat pipe concludes, that for 1 meter length of the heat pipe (the experiment was used for standard pipe depth probe) is best to use a $0.1875 \mathrm{~kg} \mathrm{CO}_{2}$, and there is a realistic prospect that the increasing amount of the substance will be power density increase. However, this conclusion has the experimentally confirmed and will require further research.

\section{Acknowledgement}

Article has been worked out in the framework of the operational programme research and development-ITMS26220220057 "Device for the use of low-potential geothermal heat without forced circulation of heat carrier in deep well pressure".

\section{References}

1. Michal Jakubský, Richard Lenhard, Jozef Jandačka. Staged the conversion of carbon dioxide in the simulator In: The application of experimental and numerical methods in fluid mechanics and energy 2012 : XVIII. international scientific conference : proceedings : 25.4.-27.4.2012 Demänovská dolina, Slovakia. - Žilina: University of Žilina, 2012. - ISBN 97880-554-0516-2. - S. 92-97

2. Richard Lenhard, Jozef Jandačka, Michal Jakubský. Zariadenia na simuláciu transformácie nizkopotenciálneho geotermálneho tepla na teplo vhodné pre vykurovanie. In: Aplikácia experimentálnych a numerických metód v mechanike tekutín a energetike : XVII. medzinárodná vedecká konferencia : Žilina - Bojnice, Slovensko 28.4.30.4.201: zborník referátov. - Žilina: Žilinská univerzita, 2010. - ISBN 978-80-554-0189-8. S. 185-189.

3. Richard Lenhard. Numerical simulation device for the transport of geothermal heat with forced circulation of media. In: Power control and optimization [elektronický zdroj] : proceeding of fourth global conference : 2-4 December 2010,
Kuching, Malaysia. - [S.1.: s.n.], 2010. - ISBN 978-983-44483-32. - [4] s.

4. D. Petráš, Nízkoteplotné vykurovanie a obnovitel'né zdroje energie, 216 (2009), ISBN 80-07-00031-5 